\title{
Clinicopathological Profile of Patients with Lung Carcinoma in a Tertiary Care Center
}

\author{
Chandramouli M.T. ${ }^{1} \quad$ Giridhar Belur Hosmane ${ }^{1}$ \\ ${ }^{1}$ Department of Pulmonary Medicine, K.S. Hegde Medical Academy, \\ Mangalore, Karnataka, India
}

Address for correspondence Chandramouli M.T., MBBS, MD, Department of Pulmonary Medicine, K. S. Hegde Medical Academy, P.O. Deralakatte, Mangaluru 575018, Karnataka, India (e-mail: mouli.aims@gmail.com).

\begin{abstract}
Keywords

- lung cancer

- smoking

- India

Introduction Among malignant diseases, lung carcinoma is the most common cancer in men worldwide in terms of both incidence and mortality. Its increasing incidence in developing countries like India is an important public health problem. This work aimed to study the demographic, clinical, radiological, and histological features of patients with confirmed lung cancer.

Materials and Methods A total of 50 patients with histologically confirmed lung cancer at a tertiary care center in India from August 2016 to September 2018 were studied and analyzed.

Results Out of 50 diagnosed lung cancer patients, $86 \%$ were men and $14 \%$ women; $31(62 \%)$ patients were aged more than 60 years. Majority were smokers $(84 \%)$ and all were men. Cough (94\%) was the most common presenting symptom followed by dyspnea (68\%), chest pain (48\%), and hemoptysis (38\%). Of the 50 patients, 29 (58\%) had soft tissue density mass lesion on radiograph. Squamous cell carcinoma (SCC) was the diagnosed histological cell type in $24(48 \%)$ patients and adenocarcinoma in $21(42 \%)$ patients. Distant metastasis was observed in 20 (40\%) patients.

Conclusion In this study, the most common histopathological cell type is SCC. Patients aged more than 50 years and smokers are at high risk of lung cancer. Patients with a smoking history and persistent respiratory symptoms should be promptly evaluated for lung malignancy.
\end{abstract}

\section{Introduction}

In developed countries, lung carcinoma is the leading cause of cancer-related deaths in both men and women, ${ }^{1}$ but its incidence and mortality rates have been falling in the last three decades. In contrast, developing nations continue to have high rates of lung cancer incidence and mortality. Most lung cancer deaths are attributable to smoking. Incidence of lung cancer is more common in males as compared with females. But its incidence and mortality are rising in females due to changing smoking patterns.

Data from GLOBOCON report 2018 reported approximately 2.1 million new cases ( $11.6 \%$ of all cancers) and 1.8 million deaths due to lung cancer ( $18.4 \%$ of all cancer-related deaths) worldwide. ${ }^{2}$ In India, 67,795 new lung cancer cases (5.9\% of all cancers) were estimated in 2018 , of which 48,698 were males. Furthermore, lung cancer caused 63,475 deaths ( $8.1 \%$ of all cancer-related deaths). ${ }^{2}$

Tobacco smoking is the primary risk factor for the development of lung cancer. ${ }^{3}$ Current smokers of one pack per day for 40 years are at high risk of developing lung cancer approximately 20 times than those who have never smoked. Other risk factors include exposure to indoor and outdoor air pollution, ${ }^{4}$ environmental tobacco smoke, ${ }^{5}$ and occupational exposure to asbestos, radon, ${ }^{6}$ nickel, arsenic, chromium. ${ }^{7}$ published online

October 21, 2020
DoI https://doi.org/

10.1055/s-0040-1718977

ISSN 2582-4287. (c) 2020. Nitte (Deemed to be University).

This is an open access article published by Thieme under the terms of the Creative Commons Attribution-NonDerivative-NonCommercial-License, permitting copying and reproduction so long as the original work is given appropriate credit. Contents may not be used for commercial purposes, or adapted, remixed, transformed or built upon. (https://creativecommons.org/licenses/by-nc-nd/4.0/).

Thieme Medical and Scientific Publishers Pvt. Ltd. A-12, 2nd Floor, Sector 2, Noida-201301 UP, India 


\section{Materials and Methods}

This was a cross-sectional observational study that included 50 patients with histologically proven primary lung cancer who visited the Department of Pulmonary medicine at a tertiary care hospital in India. Prior approval was taken from the Institutional Ethics Committee. A detailed clinical history, general physical examination, systemic examination, and diagnostic investigations (chest radiograph, ultrasonography, computed tomography [CT] of the thorax, abdomen, and brain, cytological examination of regional lymph nodes, pleural fluid analysis, CT, or bronchoscopy guided biopsy) were performed after informed written consent.

\section{Results}

A total of 50 patients were included in this study, of which 43 (86\%) were males and 7 (14\%) were females (-Table $\mathbf{1}$ ). The male to female ratio was 6.1:1. The average age of the patients was 63 years. The youngest patient was 45 years of age, whereas the oldest patient 90 years of age. More number of patients belonged to the age group of 60 to 70 years. Most of the patients (58\%) belonged to rural areas.

Majority $(n=42,84 \%)$ of patients were chronic smokers, and all were males. The smoker to never smoker ratio was 5.2:1. All female patients had a history of exposure to biomass fuel smoke. Nine patients had a prior history of pulmonary tuberculosis. Twenty-two $(n=22[44 \%])$ patients were diagnosed with chronic obstructive pulmonary disease.

The most common presenting symptoms were cough (94\%), loss of appetite and weight (82\%), dyspnea (66\%), chest pain (48\%), hemoptysis (38\%), and hoarseness of voice (6\%). Significant physical findings included digital clubbing (58\%), peripheral lymphadenopathy (18\%), and superior vena cava obstruction (12\%).

The right and left upper lobes were most affected. Of the 50 patients, $30(60 \%)$ presented with right lung lesion and $20(40 \%)$ with left lung lesion. The most common radiological abnormality was mass lesion, which was observed in 29 (58\%) patients, followed by pleural effusion (22\%), consolidation, and collapse. Other findings were mediastinal widening, cavitation, air-fluid level, nodular pattern, rib erosion, elevated hemidiaphragm, and a combination of findings.

Table 1 Demographic characteristics of patients with lung cancer

\begin{tabular}{|l|l|l|}
\hline Variables & Subgroup & $\begin{array}{l}\text { Number of patients } \\
(\boldsymbol{n}=\mathbf{5 0 )}, \boldsymbol{n}(\%)\end{array}$ \\
\hline \multirow{3}{*}{ Age (years) } & $40-50$ & $05(10)$ \\
\cline { 2 - 3 } & $51-60$ & $14(28)$ \\
\cline { 2 - 3 } & $>60$ & $31(62)$ \\
\hline \multirow{3}{*}{ Sex } & Male & $43(86)$ \\
\cline { 2 - 3 } & Female & $07(14)$ \\
\hline \multirow{2}{*}{ Smoking status } & Smokers & $42(84)$ \\
\cline { 2 - 3 } & Nonsmoker & $08(16)$ \\
\hline
\end{tabular}

In this study, 20 (40\%) patients had evidence of distant metastasis, which included metastasis in the liver (19\%), cervical lymph node (18\%), skeletal system (12\%), adrenal glands (8\%), and brain (4\%). Squamous cell carcinoma was the most common pathological type (48\%) followed by adenocarcinoma (42\%) and small cell carcinoma (6\%), and in two (4\%) patients the cell type could not be confirmed.

\section{Discussion}

In India, the incidence of lung cancer is rising due to a high prevalence of smoking. It is accountable as the third largest cause of cancer-related mortality. Among males, it is a leading cause of cancer-related mortality. However, there has been a considerable downswing in lung cancer rates in developed countries.

The average age of our patients was 63 years, with male predominance, which is similar to that reported in other Indian studies conducted by Prasad et a ${ }^{8}$ (57 years), Dey et a ${ }^{9}$ ( 60.37 years), and Kaur et al $^{10}$ ( 58.6 years). The male to female ratio was 6.1:1, which is similar to that found in other studies conducted in India by Viswanathan et $\mathrm{al}^{11}$ (ratio: 6.9:1) and Yadav et al ${ }^{12}$ (ratio: 6:1).

Similarly, the highest number of patients were in the age group of 61 to 70 years (40\%), which is similar to other Indian studies conducted by Jindal et $\mathrm{al}^{13}(37.50 \%)$, Malik et $\mathrm{al}^{14}$ (36.6\%), and Hathila et $\mathrm{al}^{15}$ (50.76\%).

In this study, majority (84\%) of patients were smokers, whereas all female patients were nonsmokers. These data are close to previous Indian studies conducted by Mohan et al ${ }^{16}$ (smokers constituted 79.3\%) and Dubey et al ${ }^{17}$ (79\% patients were smokers).

In this study, the most common radiographic findings were right lung lesion (60\%), left lung lesion (40\%), mass lesion (58\%), pleural effusion (22\%), consolidation (14\%), and cavitary lesion (6\%). Similar findings reported in studies conducted by Sharma et al ${ }^{18}$ (right lung lesion: $54.20 \%$; left lung lesion: $38.30 \%$; mass lesion: $49.90 \%$; pleural effusion: 8.80\%; consolidation: $14.20 \%$; and cavitary lesion: $8.80 \%$ ) and Saha et al ${ }^{19}$ (right lung lesion: $73.08 \%$; left lung lesion: 22.12\%; mass lesion: $26.92 \%$; consolidation: $18.27 \%$; pleural effusion: $10.58 \%$; and cavitary lesion: $8.65 \%$ ).

In this study, 24 (48\%) patients had squamous cell carcinoma, 21 (42\%) had adenocarcinoma, and 3 (6\%) had small cell carcinoma. Thus, squamous cell carcinoma was the most common histological subtype in our study followed by adenocarcinoma. Previous Indian studies have reported a similar proportion of squamous cell carcinoma compared with adenocarcinoma ( - Table 2). Currently, several studies have reported adenocarcinoma has surpassed squamous cell carcinoma as the most common histological subtype of lung cancer. ${ }^{20}$

\section{Conclusion}

Squamous cell carcinoma is the most common histological cell type followed by adenocarcinoma. Patients aged more than 50 years, males, and smokers are at high risk of 
Table 2 Comparison of the distribution of histological cell types of lung cancer in Indian studies

\begin{tabular}{|c|c|c|c|c|c|}
\hline Cell type & $\begin{array}{l}\text { Mohan et al }{ }^{16} \\
(n=397), \%\end{array}$ & $\begin{array}{l}\text { Bhadke et al }{ }^{21} \\
(n=94), \%\end{array}$ & $\begin{array}{l}\text { Hathila et al }{ }^{15} \\
(n=65), \%\end{array}$ & $\begin{array}{l}\text { Mohan et } \mathrm{al}^{20} \\
(n=1,862), \%\end{array}$ & $\begin{array}{l}\text { This study } \\
(n=50), \%\end{array}$ \\
\hline Squamous cell carcinoma & 25.1 & 32 & 61.53 & 28.6 & 48 \\
\hline Adenocarcinoma & 24.1 & 48 & 27.69 & 34.0 & 42 \\
\hline Small cell carcinoma & 14.6 & 08 & 06.15 & 16.1 & 06 \\
\hline Large cell carcinoma & 1.7 & 02 & 03.07 & NA & 0 \\
\hline Cell type undetermined & 34.5 & 10 & 01.00 & 18.1 & 04 \\
\hline
\end{tabular}

developing lung cancer. Adenocarcinoma is the common histological cell type among females and nonsmokers. Patients with a history of smoking and persistent respiratory symptoms should be promptly evaluated for lung malignancy.

\section{Conflict of Interest}

None declared.

\section{References}

1 Fitzmaurice C, Dicker D, Pain A, et al; Global Burden of Disease Cancer Collaboration. The global burden of cancer 2013. JAMA Oncol 2015;1(4):505-527

2 Bray F, Ferlay J, Soerjomataram I, Siegel RL, Torre LA, Jemal A, Global cancer statistics 2018: GLOBOCAN estimates of incidence and mortality worldwide for 36 cancers in 185 countries. Cancer J Clin; 2018 ;68(6):394-424

3 Wynder EL. Tobacco as a cause of lung cancer: some reflections. Am J Epidemiol 1997;146(9):687-694

4 Turner MC, Krewski D, Pope CA III, Chen Y, Gapstur SM, Thun MJ. Long-term ambient fine particulate matter air pollution and lung cancer in a large cohort of never-smokers. Am J Respir Crit Care Med 2011;184(12):1374-1381

5 U.S. Department of Health and Human Services. The Health Consequences of Involuntary Exposure to Tobacco Smoke: A Report of the Surgeon General. Atlanta, GA: Centers for Disease Control and Prevention; 2006

6 Committee on Health Risks of Exposure to Radon Health Effects of Exposure to Radon (BEIR VI). Washington, DC: National Academy Press, National Research Council; 1999

7 Alberg AJ, Yung R, Strickland PT, et al. Respiratory cancer and exposure to arsenic, chromium, nickel and polycyclic aromatic hydrocarbons. Clin Occup Environ Med 2002;2(4):779-780

8 Prasad R, James P, Kesarwani V, et al. Clinicopathological study of bronchogenic carcinoma. Respirology 2004;9(4):557-560

9 Dey A, Biswas D, Saha SK, Kundu S, Kundu S, Sengupta A Comparison study of clinicoradiological profile of primary lung cancer cases: an Eastern India experience. Indian J Cancer 2012;49(1):89-95
10 Kaur H, Sehgal IS, Bal A, et al. Evolving epidemiology of lung cancer in India: Reducing non-small cell lung cancer-not otherwise specified and quantifying tobacco smoke exposure are the key. Indian J Cancer 2017;54(1):285-290

11 Viswanathan R, Gupta S, Iyer PV. Incidence of primary lung cancer in India. Thorax 1962;17(1):73-76

12 Yadav D, Yadav N, Goyal R, Romana M. Role of multidetector computed tomography in evaluation of suspected bronchogenic carcinoma. Int J Res Med Sci 2016;4(3):829-835

13 Jindal SK, Malik SK, Dhand R, Gujral JS, Malik AK, Datta BN. Bronchogenic carcinoma in Northern India. Thorax 1982;37(5):343-347

14 Malik PS, Sharma MC, Mohanti BK, et al. Clinico-pathological profile of lung cancer at AIIMS: a changing paradigm in India. Asian Pac J Cancer Prev 2013;14(1):489-494

15 Hathila N, Goswami D. Radiological evaluation of various types of primary Bronchogenic carcinoma a study of 65 cases. Int J Med Sci Public Health 2016;5:919-923

16 Mohan A, Latifi AN, Guleria R. Increasing incidence of adenocarcinoma lung in India: following the global trend? Indian J Cancer 2016;53(1):92-95

17 Dubey N, Julka AR, Varudkar HG, et al. A clinico-pathological profile of primary lung cancer patients presenting in a rural medical college of Central India. J Panacea Med Sci 2015;5(3):124-129

18 Sharma CP, Behera D, Aggarwal AN, Gupta D, Jindal SK. Radiographic patterns in lung cancer. Indian J Chest Dis Allied Sci 2002;44(1):25-30

19 Saha A, Saha K, Ghosh S, Mitra M, Panchadhyayee P, Sarkar AP. Chest X-ray of lung cancer: Association with pathological subtypes. J Assoc Chest Phys 2017;5:76-80

20 Mohan A, Garg A, Gupta A, et al. Clinical profile of lung cancer in North India: a 10-year analysis of 1862 patients from a tertiary care center. Lung India 2020;37(3):190-197

21 Bhadke BB, Rathod RK, Deshmukh DG, Luniya AB, Mahajan P, Surjushe AU. Clinical profile of lung cancer in rural medical college of Maharashtra (India): a prospective study of three years. Int J Med Res Rev 2016;4(6):1063-1071 